\title{
MECHANICAL PARAMETERS OF THERMALLY MODIFIED ASH WOOD DETERMINED BY COMPRESSION IN RADIAL DIRECTION
}

\author{
Waldemar Moliński ${ }^{1}$, Edward Roszyk ${ }^{1, \star}$, Aleksander Jabloński', \\ Jakub Puszyński ${ }^{1}$, Janusz Cegiela ${ }^{1}$
}

\begin{abstract}
Mechanical parameters of ash wood (Fraxinus excelsior) subjected to compression in radial direction, before and after its thermal modification and measured at moisture content close to the equilibrium moisture content of wood exposed in and outside (4 and 12\%) were compared. Thermal modification of wood was performed at $190^{\circ} \mathrm{C}$ or $200^{\circ} \mathrm{C}$ for $2 \mathrm{~h}$ in industrial conditions. During the measurements, the moisture content of the modified and control samples was identical. The parameters compared included: modulus of elasticity, stress at proportionality limit, relative linear strain at proportionality limit and accumulated elastic energy. Changes in the mechanical parameters of wood induced by its thermal modification were found to depend on the modification temperature and wood moisture content.
\end{abstract}

Keywords: Fraxinus excelsior, mechanical properties, Thermowood, wood density, wood modification.

\section{INTRODUCTION}

Changes induced in wood by thermal treatment concern mainly hemicelluloses whose contribution, depending on the tree species, varies from 18 to 35 weight percent. The process of thermal degradation of these compounds begins at about $150^{\circ} \mathrm{C}$ and its intensity grows with increasing temperature and duration of the treatment (Fengel and Wegener 1984). High temperature causes hydrolysis and leads to a significant decrease of hydroxyl groups $(\mathrm{OH})$ responsible for bonding of water molecules. As a result of the significant decrease in the content of hemicelluloses, a substantial decrease in hygroscopicity and susceptibility of the modified wood to biotic decomposition has been noted (ThermoWood ${ }^{\circledR}$ Handbook 2003, Mazela et al. 2004, Peters et al. 2009, Mohareb et al. 2012), along with a decrease in the energy of wood cracking (Murata et al. 2013). Acetic acid released as a by-product of hemicellulose hydrolysis causes depolymerisation of cellulose, which leads to an apparent increase in its crystallinity and in the thickness of the crystallites as well as to a change in their ordering (Andersson 2006, Olek and Bonarski 2008). Besides the changes in the carbohydrate system, thermal treatment of wood also causes partial degradation of lignin which is considered the most stable chemical component of wood substance (Boonstra et al. 2007, Windeisen et al. 2009). The thermally induced changes in the chemical structure of wood are reflected in its physical-mechanical properties, e.g. a change in the wood colour after its thermal modification is correlated with the degree of crystallinity, polymerisation and content of hydroxyl groups (Bourgois et al. 1991, Bekhta and Niemz 2003, Chow and Mukai 1972). It has been shown that the colour changes in spruce, pine and beech wood upon thermal treatment can be used for prediction of the properties of the product (Johansson and Morén 2006, Brischke et al. 2007, GonzálezPeña and Hale 2009). As follows from the hitherto published reports, after thermal treatment wood can show higher compression strength and bending strength along the grains, higher linear modulus of elasticity and higher hardness. Other properties including tensile strength along and across the grains, shear strength and impact bending strength and shock resistance always deteriorate upon thermal treatment (ThermoWood ${ }^{\circledR}$ Handbook 2003, Windeisen et al. 2009). According to Li-Shi et al. (2007), 
thermal modification of a few species of Canadian wood leads to a significant decrease in its static bending strength, some decrease in the modulus of elasticity and for birch and ash wood - an increase in the modulus of elasticity by as much as 15 to $30 \%$. Another observation is that the changes in the Brinell hardness number significantly depended on the species of modified wood. For pine, spruce and birch wood an increase in the hardness was noted, while for ash wood - a decrease. Korkut and Hiziroglu (2009) have reported deterioration in the mechanical properties of hazel wood (Corylus colurna), while Gündüz et al. (2008) pointed to deterioration in the compressive strength of black pine wood (Pinus nigra) irrespectively of temperature of the treatment. For hornbeam wood the decrease in compressive strength and hardness was proportional to reduction in wood density (Gündüz et al. 2009). Similar effects of thermal treatment have been also noted for oak and sour cherry wood (Korkut and Aytin 2015). Results of the above mentioned studies differ from the earlier reports and in particular from the report of Boonstra et al. (2007) who studied wood from two pine species (Pinus radiata and Pinus sylvestris) and spruce wood (Picea abies). It should be noted that in the majority of the above mentioned works the mechanical properties of modified wood were compared with the reference data characterising control wood samples after their conditioning at the same relative humidity of air and the same temperature. Thus, the mechanical parameters of modified wood were determined at lower moisture content than those of the control samples. This fact has been pointed out by Arnold (2010) who studied the effect of moisture content on the bending strength of thermally modified beech wood.

The aim of this study is to compare the mechanical parameters of ash wood (Fraxinus excelsior) subjected to compressive stress in the radial direction before and after thermal modification, determined at the moisture content close to the equilibrium value for wood exposed in and outside. As a continuation of this study we plan to determine and compare the analogous parameters under compressive stress in the tangential direction. The decision to undertake this research was made due to, as far as the authors are concerned, the lack of information on the influence of thermal modification of ash wood on the change of mechanical parameters determined in compression test across the grains. According to the publications by Clauss et al. (2014) and Niemz et al. (2014) the influence of comparable moisture level of unmodified and modified wood would be different for both tangential directions.

\section{MATERIALS AND METHODS}

The measurements were performed on 10 radial planks of $25 \mathrm{~mm}$ in thickness and $1 \mathrm{~m}$ in length. They were divided into two groups of 5 planks each. From each plank a section of $0,35 \mathrm{~m}$ in length was cut off to be treated as control samples, while the remaining part of each plank was subjected to thermal treatment. One group of the planks was subjected to thermal treatment at $190^{\circ} \mathrm{C}$, while the other at $200^{\circ} \mathrm{C}$. The process of wood modification at either of the two temperatures was conducted for $2 \mathrm{~h}$ in industrial conditions, following the procedure proposed by Finnforest (ThermoWood ${ }^{\circledR}$ Handbook 2003, Viitaniemi et al. 1997, Militz and Altgen 2014). The plank division into the control and modified parts and way of sample obtaining are illustrated in Figure 1.

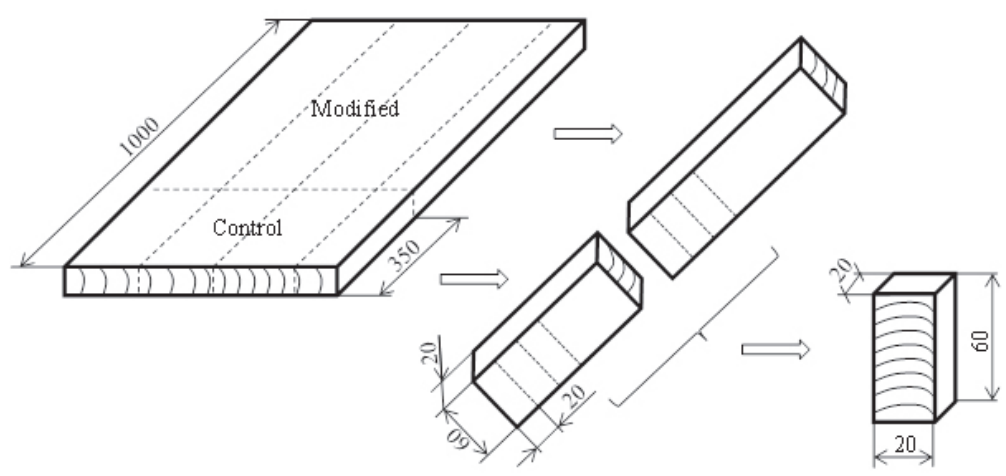

Figure 1. Method of sample obtaining (dimensions unit - millimetres). 
After thermal modification the wood samples were conditioned for one week in open air under a roof. The control parts were assigned to the corresponding modified parts. Then, along the lengths of the modified parts and the corresponding control parts of the planks, lines were drawn to mark the lines of planks cutting. The cutting was made by sawing in such a way that the fillets obtained from the modified and control parts of the planks would encompass the same annual rings. The samples were selected and divided into two twin groups. Samples from one of them were stored in the conditions ensuring the moisture content of about $4 \%$, while those from the other group were stored in the conditions ensuring the equilibrium content of about $12 \%$. Taking into account the earlier results concerning the hygroscopicity of analogous wood material (Moliński et al. 2010), the samples thermally modified were conditions at room temperatures in desiccators in which relative humidity $(\mathrm{RH})$ was 45 or $97 \%$, and the control samples were conditioned at RH of 25 or $80 \%$.

The mechanical parameters of wood under compression perpendicular to the grains were measured according to the norm PN-77/D-04229, on a numerically controlled test machine Zwick Z050. Software provided the stress-strain curve, the values of modulus of elasticity MOE [MPa], stress at proportionality limit (conventional strength) $\mathrm{s}_{\mathrm{gp}}[\mathrm{MPa}]$, relative linear strain at proportionality limit $\mathrm{e}_{\mathrm{gp}}$ $[\%]$ and accumulated elastic energy $\mathrm{U}[\mathrm{J}]$. Analogous research has also been conducted for compression test in tangential direction. However, because of the multitude of analyzed parameters and the need to compare them with parameters of unmodified wood, the results of this study will be the subject of another research paper.

\section{RESULTS AND DISCUSSION}

Analysis of the effects of thermal treatment of wood on its mechanical parameters must be made taking into account the temperature induced changes in its density. Density of wood was measured for all samples before determination of mechanical parameters at comparable moisture content varying from 3,8 to $4,2 \%$ for control samples and from 2,8 to $4,3 \%$ for thermally modified samples. Results of the measurements are given in Table 1 together with the average change in wood density caused by temperature treatment.

Table 1. Mean values of the density of control samples and the samples thermally modified at $\mathrm{T}_{1}=$ $190^{\circ} \mathrm{C}$ and $\mathrm{T}_{2}=200^{\circ} \mathrm{C}$ determined at the moisture content close to $4 \%$.

\begin{tabular}{|c|c|c|c|}
\hline \multicolumn{3}{|c|}{ Density, $\mathrm{r}\left[\mathrm{kg} / \mathrm{m}^{3}\right]$} & \multirow{2}{*}{$\begin{array}{c}\text { Average change } \\
\text { density [\%] }\end{array}$} \\
\hline Control & Modified $190^{\circ} \mathrm{C}$ & Modified $200^{\circ} \mathrm{C}$ & Min-avg-max \\
\hline $677-708-741$ & Min-avg-max & - & $-3,54$ \\
\hline $690-712-738$ & $663-683-706$ & $612-646-699$ & $-9,27$ \\
\hline
\end{tabular}

The results confirm many reports by different authors who claim that the density of wood modified in high temperature decreases and that this decrease is the greater the higher the temperature (ThermoWood $^{\circledR}$ Handbook 2003, Borrega and Kärenlampi 2008, Gündüz et al. 2008, Gündüz et al. 2009, González-Peña and Hale 2009, Moliński et al. 2010). A decrease in wood density as a result of thermal treatment points to the escape of volatile products of wood degradation. The decrease in mass of the wood is greater than the contraction of its volume, both expressed in percentage. Degradation of the wood components, mainly hemicelluloses, leads to a decrease in the number of hydroxyl groups (Weiland and Guyonnet 2003).

The determined mechanical parameters of wood samples are presented in Tables 2-5. Tables 2 and 3 present the results for the control samples and the samples modified at 190 and $200^{\circ} \mathrm{C}$ determined at the moisture content $4 \%$, while Tables 4 and 5 present analogous results but determined at the moisture content $12 \%$. The Tables also show the changes in the mean values of the parameters caused by the thermal modification of wood. As follows from analysis of these data, as a result of thermal treatment the original wood properties change to a degree dependent on the temperature of modification and 
moisture content at the time of measurements of the mechanical parameters. The wood modified at $190^{\circ} \mathrm{C}$ and having moisture content of about $4 \%$, shows conventional compressive strength (stress at proportionality limit) in radial direction by about $18 \%$ greater than that of control wood. An increase to an even greater degree, to over $22 \%$, was noted in the conventional specific strength $\left(\mathrm{s}_{\mathrm{gpw}}\right)$ defined as the ratio of stress at proportionality limit (conventional strength, $\mathrm{s}_{\mathrm{gp}}$ ) and wood density $(\rho)$ :

$$
\sigma_{g p w}=\frac{\sigma_{g p}[\mathrm{MPa}]}{\rho\left[\frac{\mathrm{kg}}{\mathrm{m}^{3}}\right]} \quad\left[\frac{10^{6} \mathrm{Nm}^{3}}{\mathrm{~m}^{2} \mathrm{~kg}}=10^{6} \frac{\mathrm{Nm}}{\mathrm{kg}}\right]
$$

Table 2. Mechanical parameters of the control samples and the samples modified at $190^{\circ} \mathrm{C}$ at moisture content close to $4 \%$.

\begin{tabular}{|c|c|c|c|c|}
\hline \multirow{2}{*}{$\begin{array}{l}\text { Mechanical } \\
\text { parameter }\end{array}$} & \multicolumn{4}{|c|}{ Basic statistical parameters } \\
\hline & Min-avg-max & $\begin{array}{c}\text { Mean change } \\
{[\%]}\end{array}$ & $\begin{array}{c}\text { Standard deviation, } \\
\pm \mathrm{S}\end{array}$ & $\begin{array}{c}\text { Variability } \\
\text { coefficient, V [\%] }\end{array}$ \\
\hline $\begin{array}{c}\text { Stress at } \\
\text { proportionality } \\
\text { limit, } \mathrm{s}_{\mathrm{gp}}[\mathrm{MPa}]\end{array}$ & $\begin{array}{l}8,26-9,73-11,84^{*} \\
9,00-11,55-14,50\end{array}$ & +18 & $\begin{array}{l}1,23 \\
1,52\end{array}$ & $\begin{array}{l}12,69 \\
13,12\end{array}$ \\
\hline $\begin{array}{c}\text { Strain at } \\
\text { proportionality } \\
\text { limit, } \mathrm{e}_{\mathrm{gp}}[\%]\end{array}$ & $\begin{array}{l}0,51-0,74-1,30 \\
0,43-0,72-1,22\end{array}$ & $-2,7$ & $\begin{array}{l}0,19 \\
0,22\end{array}$ & $\begin{array}{l}26,20 \\
30,24\end{array}$ \\
\hline $\begin{array}{c}\text { Modulus } \\
\text { of elasticity, } \\
\text { MOE [MPa] }\end{array}$ & $\begin{array}{l}993-1770-2501 \\
1198-1977-2302\end{array}$ & $+11,7$ & $\begin{array}{l}437,8 \\
299,1\end{array}$ & $\begin{array}{l}24,73 \\
15,13\end{array}$ \\
\hline $\begin{array}{l}\text { Elastic energy, } \\
\mathrm{U}[\mathrm{J}]\end{array}$ & $\begin{array}{l}0,516-0,750-1,712 \\
0,474-0,929-1,650\end{array}$ & $+23,8$ & $\begin{array}{l}0,28 \\
0,32\end{array}$ & $\begin{array}{l}37,33 \\
34,25\end{array}$ \\
\hline $\begin{array}{c}\text { Conventional } \\
\text { specific } \\
\text { strength, } \mathrm{s}_{\mathrm{gpw}} \\
{[\mathrm{MNm} / \mathrm{kg}] \mathrm{x}} \\
10^{2} \\
\end{array}$ & $\begin{array}{l}1,12-1,38-1,71 \\
1,34-1,69-2,12\end{array}$ & $+22,5$ & $\begin{array}{l}0,19 \\
0,21\end{array}$ & $\begin{array}{l}13,93 \\
12,60\end{array}$ \\
\hline
\end{tabular}


Table 3. Mechanical parameters of the control samples and the samples modified at $200^{\circ} \mathrm{C}$ at moisture content close to $4 \%$.

\begin{tabular}{|c|c|c|c|c|}
\hline \multirow{2}{*}{$\begin{array}{c}\text { Mechanical } \\
\text { parameter }\end{array}$} & \multicolumn{4}{|c|}{ Basic statistical parameters } \\
\hline & Min-avg-max & $\begin{array}{c}\text { Mean change } \\
{[\%]}\end{array}$ & $\begin{array}{c}\text { Standard deviation, } \\
\pm \mathrm{S}\end{array}$ & $\begin{array}{c}\text { Variability } \\
\text { coefficient, V [\%] }\end{array}$ \\
\hline $\begin{array}{c}\text { Stress at } \\
\text { proportionality } \\
\text { limit, } \mathrm{s}_{\mathrm{gp}}[\mathrm{MPa}]\end{array}$ & $\begin{array}{c}7,98-10,18-14,20^{*} \\
2,08-8,04-10,40\end{array}$ & $-21,0$ & $\begin{array}{l}1,39 \\
2,38\end{array}$ & $\begin{array}{l}13,69 \\
29,56\end{array}$ \\
\hline $\begin{array}{c}\text { Strain at } \\
\text { proportionality } \\
\text { limit, } \mathrm{e}_{\mathrm{gp}}[\%]\end{array}$ & $\begin{array}{l}0,43-0,66-0,95 \\
0,19-0,50-0,72\end{array}$ & $-24,2$ & $\begin{array}{l}0,15 \\
0,13\end{array}$ & $\begin{array}{l}23,42 \\
26,72\end{array}$ \\
\hline $\begin{array}{c}\text { Modulus of } \\
\text { elasticity, MOE } \\
{[\mathrm{MPa}]} \\
\end{array}$ & $\begin{array}{l}1560-1960-2315 \\
1398-1756-2191\end{array}$ & $-10,5$ & $\begin{array}{l}222,9 \\
291,7\end{array}$ & $\begin{array}{l}11,37 \\
16,61\end{array}$ \\
\hline $\begin{array}{c}\text { Elastic energy, } \\
\mathrm{U}[\mathrm{J}]\end{array}$ & $\begin{array}{l}0,374-0,718-1,480 \\
0,065-0,499-0,840 \\
\end{array}$ & $-30,5$ & $\begin{array}{l}0,24 \\
0,22 \\
\end{array}$ & $\begin{array}{l}33,79 \\
44,45 \\
\end{array}$ \\
\hline $\begin{array}{c}\text { Conventional } \\
\text { specific strength, } \\
\mathrm{s}_{\mathrm{gpw}}[\mathrm{MNm} / \mathrm{kg}] \\
\mathrm{x} 10^{2}\end{array}$ & $\begin{array}{l}1,12-1,43-2,02 \\
0,45-1,25-1,68\end{array}$ & $-12,6$ & $\begin{array}{l}0,21 \\
0,39\end{array}$ & $\begin{array}{l}14,37 \\
31,51\end{array}$ \\
\hline
\end{tabular}

Table 4. Mechanical parameters for the control samples and the samples modified at $190^{\circ} \mathrm{C}$ at moisture content close to $12 \%$.

\begin{tabular}{|c|c|c|c|c|}
\hline \multirow[b]{2}{*}{$\begin{array}{l}\text { Mechanical } \\
\text { parameter }\end{array}$} & \multicolumn{4}{|c|}{ Basic statistical parameters } \\
\hline & Min-avg-max & $\begin{array}{c}\text { Mean change } \\
{[\%]} \\
\end{array}$ & $\begin{array}{c}\text { Standard deviation, } \\
\pm \mathrm{S}\end{array}$ & $\begin{array}{c}\text { Variability } \\
\text { coefficient, V [\%] }\end{array}$ \\
\hline $\begin{array}{c}\text { Stress at } \\
\text { proportionality } \\
\text { limit, } s_{\mathrm{gp}}[\mathrm{MPa}]\end{array}$ & $\begin{array}{c}6,13-7,46-10,40 * \\
3,84-4,71-6,03\end{array}$ & $-36,8$ & $\begin{array}{l}1,22 \\
0,62\end{array}$ & $\begin{array}{l}16,30 \\
13,06\end{array}$ \\
\hline $\begin{array}{l}\text { Strain at } \\
\text { proportionality } \\
\text { limit, } \mathrm{e}_{\mathrm{gp}}[\%]\end{array}$ & $\begin{array}{l}0,53-0,76-1,07 \\
0,48-0,62-0,76\end{array}$ & $-18,5$ & $\begin{array}{l}0,18 \\
0,10\end{array}$ & $\begin{array}{l}24,11 \\
15,78\end{array}$ \\
\hline $\begin{array}{c}\text { Modulus of } \\
\text { elasticity, MOE } \\
{[\mathrm{MPa}]}\end{array}$ & $\begin{array}{c}860-1272-1818 \\
640-925-1179\end{array}$ & $-37,3$ & $\begin{array}{l}286,2 \\
133,4\end{array}$ & $\begin{array}{l}22,50 \\
14,43\end{array}$ \\
\hline $\begin{array}{c}\text { Elastic energy, } \\
\mathrm{U}[\mathrm{J}]\end{array}$ & $\begin{array}{l}0,365-0,625-1,170 \\
0,266-0,348-0,499\end{array}$ & $-44,3$ & $\begin{array}{l}0,19 \\
0,07\end{array}$ & $\begin{array}{l}30,62 \\
19,85\end{array}$ \\
\hline $\begin{array}{c}\text { Conventional } \\
\text { specific } \\
\text { strength, } \mathrm{s}_{\mathrm{gpw}} \\
{[\mathrm{MNm} / \mathrm{kg}]} \\
\mathrm{x} 10^{2}\end{array}$ & $\begin{array}{l}0,82-1,03-1,44 \\
0,55-0,67-0,87\end{array}$ & $-35,0$ & $\begin{array}{l}0,17 \\
0,09\end{array}$ & $\begin{array}{l}16,54 \\
13,42\end{array}$ \\
\hline
\end{tabular}


Table 5. Mechanical parameters for the control samples and the samples modified at $200^{\circ} \mathrm{C}$ at moisture content close to $12 \%$.

\begin{tabular}{|c|c|c|c|c|}
\hline \multirow{2}{*}{$\begin{array}{l}\text { Mechanical } \\
\text { parameter }\end{array}$} & \multicolumn{4}{|c|}{ Basic statistical parameters } \\
\hline & Min-avg-max & $\begin{array}{c}\text { Mean change } \\
{[\%]}\end{array}$ & $\begin{array}{c}\text { Standard deviation, } \\
\pm \mathrm{S}\end{array}$ & $\begin{array}{c}\text { Variability } \\
\text { coefficient, V [\%] }\end{array}$ \\
\hline $\begin{array}{c}\text { Stress at } \\
\text { proportionality } \\
\text { limit, } s_{\mathrm{gp}}[\mathrm{MPa}]\end{array}$ & $\begin{array}{c}3,95-6,93-7,89 * \\
2,19-4,13-5,87\end{array}$ & $-40,5$ & $\begin{array}{l}0,92 \\
1,16\end{array}$ & $\begin{array}{l}13,22 \\
28,13\end{array}$ \\
\hline $\begin{array}{c}\text { Strain at } \\
\text { proportionality } \\
\text { limit, } e_{g p}[\%]\end{array}$ & $\begin{array}{l}0,22-0,66-0,96 \\
0,19-0,54-0,97\end{array}$ & $-18,2$ & $\begin{array}{l}0,19 \\
0,19\end{array}$ & $\begin{array}{l}29,15 \\
35,05\end{array}$ \\
\hline $\begin{array}{c}\text { Modulus of } \\
\text { elasticity, MOE } \\
{[\mathrm{MPa}]}\end{array}$ & $\begin{array}{c}949-1306-1730 \\
435-901-1428\end{array}$ & $-31,1$ & $\begin{array}{l}231,2 \\
280,1\end{array}$ & $\begin{array}{l}17,70 \\
31,08\end{array}$ \\
\hline $\begin{array}{c}\text { Elastic energy, } \\
\mathrm{U}[\mathrm{J}]\end{array}$ & $\begin{array}{l}0,131-0,530-0,706 \\
0,057-0,280-0,496\end{array}$ & $-47,2$ & $\begin{array}{l}0,15 \\
0,11 \\
\end{array}$ & $\begin{array}{l}29,23 \\
38,59 \\
\end{array}$ \\
\hline $\begin{array}{c}\text { Conventional } \\
\text { specific strength, } \\
\mathrm{s}_{\mathrm{gpw}}[\mathrm{MNm} / \mathrm{kg}] \\
\mathrm{x} 10^{2} \\
\end{array}$ & $\begin{array}{l}0,55-0,98-1,09 \\
0,34-0,62-0,90\end{array}$ & $-36,7$ & $\begin{array}{l}0,13 \\
0,19\end{array}$ & $\begin{array}{l}13,18 \\
30,10\end{array}$ \\
\hline
\end{tabular}

*top verse gives the values for the control samples, bottom verse - for the modified samples.

The greater increase in specific strength than in conventional strength, expressed in [MPa], is a consequence of the wood density reduction caused by thermal treatment. The modulus of elasticity of thermally modified wood in radial direction is almost $12 \%$ higher and elastic energy almost $24 \%$ higher than the non-treated samples. The mechanical parameters of wood modified at $190^{\circ} \mathrm{C}$ higher than those of the starting material suggest that this thermally treated wood can be attractive for production of floors, e.g. parquet. It should be noted that improvement in certain mechanical parameters of wood, in particular its rigidity and hardness, occurring as a result of thermal modification, has been reported earlier (Boonstra et al. 2007, Li Shi et al. 2007). Although the mechanical parameters of wood subjected to thermal modification at $190^{\circ} \mathrm{C}$, measured in the radial direction at moisture content of about $4 \%$, were higher than those determined for unmodified wood, the parameters found for the wood modified at $200^{\circ} \mathrm{C}$ were much lower (Table 4). The greatest decrease, by about $30 \%$, was observed for the elastic energy accumulated in the samples loaded to the stress at proportionality limit. The value of this energy is assumed as the basic descriptor of initiation of wood cracking (Koji et al. 2013). In general, the higher this energy the greater the resistance of wood to brittle cracking (Gibson and Ashby 1997). The wood modified at $200^{\circ} \mathrm{C}$ is much more brittle than the control sample and the sample modified at $190^{\circ} \mathrm{C}$. The significant decrease in the elastic energy of wood modified at $200^{\circ} \mathrm{C}$ is a result of diminished strain (by 24\%) and stress at the limit of proportionality (by 21\%) as well as a decrease in the modulus of elasticity (by 10,5\%).

Mechanical parameters of wood modified at $190^{\circ} \mathrm{C}$ and determined at the relative moisture content close to $4 \%$ were higher than those determined for control samples, but those of wood modified at the same temperature but determined at the relative moisture content close to $12 \%$ were much lower than those of the control samples, see Table 3. As follows from Table 3, the stress at proportionality limit and modulus of elasticity were by as much as $37 \%$ lower than those in the control samples. The elastic energy decreased even more, by about $44 \%$. The influence of wood moisture content on its mechanical parameters is generally known, with increasing moisture content the mechanical parameters of wood decrease and the degree of this decrease depends on the type of stress applied and wood species (Winandy and Rowell 1984, Green et al. 1999, Korkut and Aytin 2015). The compressive strength of wood exhibits the greatest decrease. The compressive strength of wet wood (mainly the compressive strength along the grains) can make only $25 \%$ of the value in completely dry state (Kollmann and Côté 
1984). In view of the above, a decrease in the mechanical parameters of wood subjected to thermal treatment with increasing moisture content is expected. An important observation is that for the wood modified at $190^{\circ} \mathrm{C}$ at moisture content of $12 \%$, the scatter of the values of mechanical parameters measured gets narrowed, so that the variation coefficient is smaller than for control wood. This fact can be explained by the fact that increased moisture content of wood whose structure has been partly defected by thermal treatment leads to more homogeneous distribution of internal stress, so the regions responding to external stress is enlarged and stress accumulation decreases. This positive effect of plasticising effect of water can be observed only if the original structure of wood has been only to a relatively small degree degraded upon its thermal treatment. The greater destruction of wood tissue caused by thermal treatment at $200^{\circ} \mathrm{C}$, leads not only to a significant deterioration of mechanical parameters measured (Table 5), but also to an increase in their variation range.

To analyse the effect of moisture content on the values of wood parameters measured, the change in the parameters taking place upon increasing moisture content in the samples studied from the first to the second level. The calculations were made for the mean values of the parameters measured taking into account the fact that the moisture contents of particular populations of samples were slightly different. The decrease in the parameters analysed was calculated from the formula:

$$
\Delta W=\frac{W_{1}-W_{2}}{\Delta u}[M P a / \% ; J / \% ; \% / \%],
$$

where: DW - change in a given parameter corresponding to the moisture content increase by one percent, $\mathrm{W}_{1}$ - mean value of a given parameter at low moisture content, $\mathrm{W}_{2}$ - mean value of a given parameter at high moisture content, Du - mean difference in moisture content for a given population.

The real values of moisture content for particular populations of samples and the range of its values are given in Table 6. According to these data, conditioning of the modified samples over a water table gave the mean moisture content by 5,7 and $2,9 \%$ (for samples modified at $\mathrm{T}=190^{\circ} \mathrm{C}$ and $\mathrm{T}=200^{\circ} \mathrm{C}$, respectively) higher than the mean moisture contents control samples conditioned above supersaturated solution of salt. The higher moisture content of the samples conditioned over a water table and modified at $190^{\circ} \mathrm{C}$ than of those modified at $200^{\circ} \mathrm{C}$ follows from the known influence of wood modification temperature on its equilibrium moisture content (Moliński et al. 2010).

Table 6. Range variation of the real values of moisture content for particular populations of samples and mean difference in moisture content in moisture content at the two assumed levels.

\begin{tabular}{|c|c|c|c|}
\hline \multirow{3}{*}{ Type of sample } & \multicolumn{2}{|c|}{ Moisture content [\%] } & \multirow{3}{*}{$\begin{array}{c}\text { Mean difference in } \\
\text { moisture content Du } \\
{[\%]}\end{array}$} \\
\hline & 4 & 12 & \\
\hline & Min-avg-max & Min-avg-max & \\
\hline Control sample $\mathrm{T}_{1}$ & $3,96-4,09-4,23$ & $11,70-12,04-12,39$ & 7,95 \\
\hline $\begin{array}{c}\text { Sample modified at } \\
\mathrm{T}_{1}=190^{\circ} \mathrm{C}\end{array}$ & $2,82-3,79-4,34$ & $16,37-17,83-18,94$ & 14,04 \\
\hline Control sample $\mathrm{T}_{2}$ & $3,83-3,93-4,12$ & $11,92-12,80-12,39$ & 8,2 \\
\hline $\begin{array}{c}\text { Sample modified at } \\
\mathrm{T}_{2}=200^{\circ} \mathrm{C}\end{array}$ & $2,29-2,72-3,60$ & $14,41-15,23-16,04$ & 12,51 \\
\hline
\end{tabular}

Taking into account the actual difference in moisture content, the changes in mechanical parameters of wood under compression in radial direction per $1 \%$ increase in the moisture content of the samples, were calculated and are presented in Table 7. According to these data, the influence of increased moisture content of wood on the mechanical parameters measured is greater for wood subjected to thermal treatment than for the control samples. It is particularly well pronounced for elastic energy and conventional specific strength. Comparing the mechanical parameters determined for the wood thermally treated at both temperatures and the corresponding control samples, (Table 7) 
only the decrease in the modulus of elasticity per $1 \%$ increase in the moisture content is similar. The other parameters such as the stress at proportionality limit, elastic energy and conventional specific strength decrease with increasing moisture content by much more for the modified wood than for the control samples.

Table 7. Relative changes in mechanical parameters of control samples and thermally modified samples per $1 \%$ increase in moisture content.

\begin{tabular}{|c|cccc|}
\hline \multirow{2}{*}{ Type of sample } & $\begin{array}{c}\text { Stress at } \\
\text { proportionality } \\
\text { limit, } \mathrm{s}_{\mathrm{gp}}[\mathrm{MPa}]\end{array}$ & $\begin{array}{c}\text { Modulus of } \\
\text { elasticity, } \\
\text { MOE }[\mathrm{MPa}]\end{array}$ & $\begin{array}{c}\text { Elastic energy, } \\
\mathrm{U}[\mathrm{J}]\end{array}$ & $\begin{array}{c}\text { Conventional } \\
\text { specific strength, } \\
\mathrm{s}_{\mathrm{gpw}}[\mathrm{MNm} / \mathrm{kg}] \\
\mathrm{x} 10^{2}\end{array}$ \\
\cline { 2 - 5 } & $\begin{array}{c}\text { Relative change corresponding to moisture content } \\
\text { (a coefficient) }\end{array}$ \\
\hline Control sample $\mathrm{T}_{1}$ & 0,0298 & 0,0354 & 0,0267 & 0,0290 \\
\hline $\begin{array}{c}\text { Sample modified at } \\
\mathrm{T}_{1}=190^{\circ} \mathrm{C}\end{array}$ & 0,0424 & 0,0379 & 0,0431 & 0,0414 \\
\hline${\text { Control sample } \mathrm{T}_{2}}^{\text {Conte }}$ & 0,0393 & 0,0407 & 0,0278 & 0,0349 \\
\hline $\begin{array}{c}\text { Sample modified at } \\
\mathrm{T}_{2}=200^{\circ} \mathrm{C}\end{array}$ & 0,0386 & 0,0389 & 0,0401 & 0,0400 \\
\hline $\begin{array}{c}\text { Control sample } \\
\text { (mean) }\end{array}$ & 0,0345 & 0,0380 & 0,0272 & 0,0320 \\
\hline $\begin{array}{c}\text { Modified sample } \\
\text { (mean) }\end{array}$ & 0,0405 & 0,0384 & 0,0421 & 0,0410 \\
\hline
\end{tabular}

The differences in the moisture content effect on the wood mechanical parameters between the modified and control samples are the most pronounced in elastic energy (54\%), conventional specific strength (28\%), stress at proportionality limit (17\%), but not in the modulus of elasticity.

\section{CONCLUSIONS}

The above presented and discussed results permit drawing the following conclusions.

The process of thermal modification of wood leads to a decrease in its density; the higher the temperature of modification the greater the decrease in wood density. Also greater decrease in wood density was observed for samples of greater starting density.

Thermal modification of ash wood at $190^{\circ} \mathrm{C}$ resulted in improvement in its compression in radial direction, but only for the samples of low moisture content (close to $4 \%$ ).

Compression in radial direction of ash wood determined for the samples of high moisture content (close $12 \%$ ) and ash wood modified at $200^{\circ} \mathrm{C}$ irrespective of its moisture content, are much lower than those for the control samples.

Compression in radial direction of thermally modified wood decrease with its increasing moisture content to a much greater degree than the parameters characterising the control wood samples.

\section{REFERENCES}

Andersson, S. 2006. A study of the nanostructure of the cell wall of the tracheids of conifer xylem by x-ray scattering. University of Helsinki report series in physics HU-PD135: 1-35. 
Arnold, M. 2010. Effect of moisture on the bending properties of thermally modified beech and spruce. Journal of Materials Science 45(3):669-680.

Bekhta, P.; Niemz, P. 2003. Effect of high temperature on the change in color, dimensional stability and mechanical properties of spruce wood. Holzforschung 57(5):539-546.

Boonstra, M. J.; Van Acker, J.; Tjeerdsma, B. F.; Kegel, E. F. 2007. Strength properties of thermally modified softwoods and its relation to polymeric structural wood constituents. Annals of Forest Science 64(7):679-690.

Borrega, M.; Kärenlampi, P.P. 2008. Mechanical behavior of heat-treated spruce (Picea abies) wood at constant moisture content and ambient humidity. European Journal of Wood and Wood Products 66(1):63-69.

Bourgois, J.; Janin, G.; Guyonnet, R. 1991. Measuring colour: a method of studying and optimizing the chemical transformations of thermally-treated wood. Holzforschung 45(5):377-382.

Brischke, C.; Welzbacher, C.R.; Brandt, K.; Rapp, A.O. 2007. Quality control of thermally modified timber: Interrelationship between heat treatment intensities and CIE $\mathrm{L}^{*} \mathrm{a} * \mathrm{~b} *$ color data on homogenized wood samples. Holzforschung 61(1):19-22.

Chow, S. Z.; Mukai, H.N. 1972. Effect of thermal degradation of cellulose on wood-polymer bonding. Wood Science 4(4):202-208.

Clauss, S.; Pescatore, C.; Niemz, P. 2014. Anisotropic elastic properties of common ash (Fraxinus excelsior L.). Holzforschung 68(8):941-949.

Fengel, D.; Wegener, G. 1984. Wood, chemistry, ultrastructure, reactions. Walter de Gruyter \& Co., Berlin.

Gibson, L. J.; Ashby, M.F. 1997. Cellular solids. Structural and properties. Second edition. Cambridge Univ. Press.

González-Peña, M.M.; Hale, M.D.C. 2009. Colour in thermally modified wood of beech, Norway spruce and Scots pine. Part 2: Property predictions from colour changes. Holzforschung 63(4):394-401.

Green, D.W.; Winandy, J.E.; Kretschmann, D.E. 1999. Mechanical properties of wood - wood as an engineering material. General Technical Report FPL-TR 113, U.S. Department of Agriculture, Forest Service, Forest Products Laboratory, Madison, WI.

Gündüz, G.; Korkut, S.; Korkut, D.S. 2008. The effects of heat treatment on physical and technological properties and surface roughness of Camiyanı Black Pine (Pinus nigra Arn. subsp. pallasiana var. pallasiana) wood. Bioresource Technology 9(7):2275-2280.

Gündüz, G.; Korkut, S.; Aydemir, D.; Bekar, I. 2009. The density, compression strength and surface hardness of heat-treated Hornbeam (Carpinus betulus L.) wood. Maderas. Ciencia y tecnologia 11(1):61-70.

Johansson, D.; Morén, T. 2006. The potential of colour measurement for strength prediction of thermally treated wood. European Journal of Wood and Wood Products 64(2):104-110.

Koji, M.; Yasuhiro, W.; Takato, N. 2013. Effect of thermal treatment on fracture properties and adsorption properties of Spruce wood. Materials 6(9):4186-4197.

Kollmann, F. F. P.; Côté, W.A. J. 1984. Principles of wood science and technology I. Solid wood. Springer-Verlag, Berlin. 
Korkut, S.; Aytin, A. 2015. Evaluation of physical and mechanical properties of wild cherry wood heat-treated using the thermowood process. Maderas. Ciencia y tecnologia 17(1):171-178.

Korkut, S.; Hiziroglu, S. 2009. Effect of heat treatment on mechanical properties of hazelnut wood (Corylus colurna L.). Materials \& Design 30(5):1853-1858.

Li-Shi, J.; Kocaefe, D.; Zhang, J. 2007. Mechanical behavior of Québec wood species heattreated using ThermoWood process. Holz als Roh- und Werkstoff 65(4):255-259.

Mazela, B.; Zakrzewski, R.; Grześkowiak, W.; Cofta, G.; Bartkowiak, M. 2004. Resistance of thermally modified wood to basidiomycetes. Electronic Journal of Polish Agricultural Universities 7(1): wood series.

Militz H.; Altgen, M. 2014. Processes and properties of thermally modified wood manufactured in Europe. ACS Symposium Series 1158:269-285.

Mohareb, A.; Sirmah, P.; Pétrissans, M.; Gérardin, F. 2012. Effect of heat treatment intensity on wood chemical composition and decay durability of Pinus patula. European Journal of Wood and Wood Products 70:519-524.

Moliński, W.; Fabisiak, E.; Szwaba, T. 2010. Properties of thermally modified Ash wood (Fraxinus americana) in the aspect of its affinity to water. Ann WULS-SGGW For Wood Technol 72:2731.

Murata, K.; Watanabe, Y.; Nakano, T.2013. Effect of thermal treatment on fracture properties and adsorption properties of Spruce wood. Materials 6(9):4186-4197.

Niemz, P.; Clauss, S.; Michel, F.; Hansch, D.; Hansel, A. 2014. Physical and mechanical properties of common ash (Fraxinus excelsior L.). Wood Research 59(4):671-682.

Olek, W.; Bonarski, J.T. 2008. Texture changes in thermally modified wood. Archives of Metallurgy and Materials 53(1):207-211.

Peters, J.; Pfriem, A.; Horbens, M.; Fischer, S.; Wagenführ, A. 2009. Emissions from thermally modified beech wood, their reduction by solvent extraction and fungicidal effect of the organic solvent extracts. Wood Materials Science and Engineering 4(1-2):61- 66.

PN-77/D-04229 Drewno. Oznaczanie wytrzymałości na ściskanie w poprzek włókien (Wood. Determination of compression strength across the grain - standard in Polish).

Thermowood $^{\circledR}$ Handbook. 2003. Finnish Thermowood Association, Helsinki (http://www. vanhoorebeke.com/docs/Thermowood\%20handboek.pdf).

Viitaniemi, P.; Jämsä, S.; Viitanen, H. 1997. Method for improving biodegradation resistance and dimensional stability of cellulosic products. United States Patent $\mathrm{N}^{\mathrm{o}} 5678324$ (US005678324).

Weiland, J.; Guyonnet, R. 2003. Study of chemical modifications and fungi degradation of thermally modified wood using DRIFT spectroscopy. Holz als Roh- und Werkstoff 61(3):216-220.

Winandy, J.E.; Rowell, R.M. 1984. The chemistry of wood strength. In: The Chemistry of Solid Wood. ACS Symposium Series 208.Ed. Rowell, R.M. American Chemical Society, Washington, DC. pp. 211-255.

Windeisen, E.; Bächle, H.; Zimmer, B.; Wegener, G. 2009. Relations between chemical changes and mechanical properties of thermally treated wood. Holzforschung 63(6):773-778. 